特集 8

リンパ節転移度による胸部食道癌術後合併療法 一その反省と新しい試み一

\begin{tabular}{|c|c|c|c|c|c|c|}
\hline \multicolumn{7}{|c|}{ 東北大学第 2 外科 } \\
\hline 西平 & 哲郎 & 平山 & 克 & 大森 & 典夫 & 北村 道彦 \\
\hline 豊田 & 統夫 & 丹 & 正義 & 河内 & 三郎 & 蔵本 純一 \\
\hline 加納 & 正道 & 赤石 & 隆 & 佐藤 & 智 & 標葉隆三郎 \\
\hline 二宮 & 健次 & 関根 & 義人 & 片山 & 正文 & 実方 一典 \\
\hline 田 & 和徳 & 葛西 & 森夫 & & & \\
\hline
\end{tabular}

\title{
THE POSTOPERATIVE COMBINED THERAPY FOR CARCINOMA OF THE THORACIC ESOPHAGUS COMPLYING WITH THE EXTENT OF LYMPH NODE METASTASIS
}

Tetsuro NISHIHIRA, Katsu HIRAYAMA, Norio OMORI, Michihiko KITAMURA, Tsuneo TOYODA, Masayoshi TAN, Saburo KAW ACHI, Junichi KURAMOTO, Tadamichi KANO, Takashi AKAISHI, Satoru SATO, Ryuzaburo Shineha, Kenji NINOMIYA, Yoshito SEKINE, Masafumi KATAYAMA, Kazunori Sanekata, Kazunori YOSHIDA and Morio KASAI

The Second Department of Surgery, Tohoku University School of Medicine

索引用語：食道癌の遠隔成績, 食道癌術後合併療法, 食道癌

はじめに

食道癌手術の直接成續は近年著しく向上した。他方, 遠隔成績は現在なお不良であり, 他消化器癌の成績と 比較しても満足のできるすのではない.

教室では，食道癌患者の一番の願望である経口摄取 を可及的に早期にかなえる方針を堅持しつつ，積極的 な外科治療を行ってきたが，その遠隔成績の改善には 手術単独では限界があるため, 術後に施行する合併療 法の進歩による所が大きいことはこれまでにも報告し てきた . 一方, 最近になり治療成績と合併療法とのか かわりを詳細に検討した結果，さらに改善すべき諸問 題の存在することに気付いたため，これまでの合併療

※第24回日消外会総会シンボ I：遠隔成績よりみた食 道癌治療上の問題点 $<1984$ 年11月12日受理 >別刷請求先：西平 哲郎 干980 仙台市星陵町 1-1 東北大学医学部第 2 外 科
法の反省とともに改良した合併療法について述べた い.

\section{I) 症例の概要}

昭和 38 年から昭和 58 年までの 21 年間に東北大学第 2 外科に打いて切除した胸部食道癌症例は入院総数 661 例中 482 例 $(72.9 \%$ ) であり，そのらち400例が治瘁切 除である. 手術直接死亡数は54例 (11.2\%) であるが， 最近 10 年間の直死数は 240 例中 7 例 $(2.9 \%$ )であり， 昭和 38 年から 43 年 の $26.4 \%$ ，昭和 44 年から48年の $11.5 \%$ に比較して著明な改善をみている1．

手術直接死亡や明らかな他病死を除く治瘱切除症例 の 5 年生存率は $36.2 \%$ であり，10年前の 5 生率 $29.0 \%$ に比べて向上をみた。

\section{II）治療方針に関して}

a 因子の予後決定因子としての重要性に関しては, 以前より数多くの施設から報告されて扣り, その臨床 的意義から術前照射を行ら最大の理論的根拠とすなっ 
図 1 胸部食道癌治瘜切除症例の遠隔成績

- $\mathrm{a}$ 因子別生存率の比較一

$\mathrm{n}(-)$ 症例

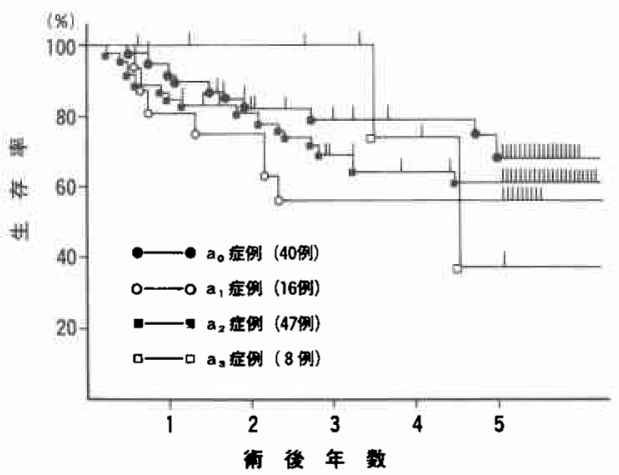

（昭38～昭58, 東北大 2 外）

$\mathrm{n}_{1}(+) \cdot \mathrm{n}_{2}(+)$ 症例

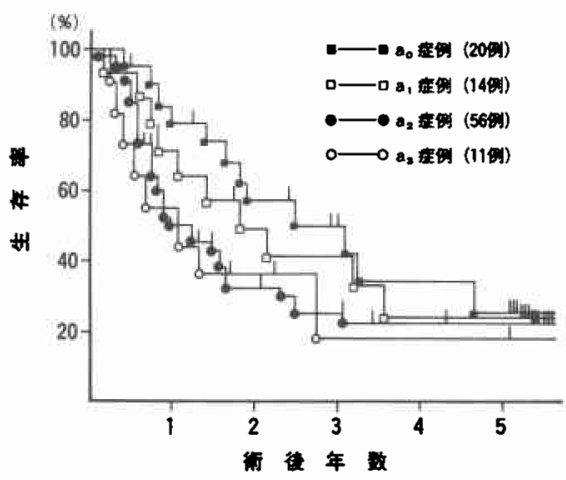

図 2 胸部食道癌治㾤切除症例の遠隔成績 一 $\mathbf{n}$ 因子別生存率の比較一

$a_{0}$ 症例

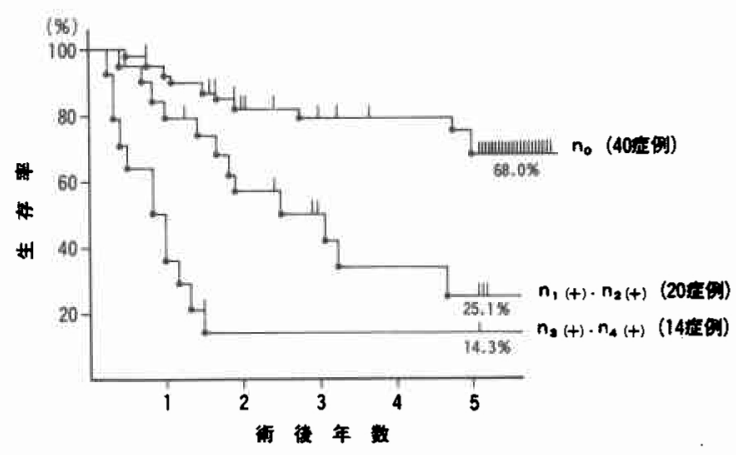

ている. 事実, 本邦では中山2)の報告以来, 食道癌手術 には術前照射が必須と思われるくらいに広く普及して いる.しかし，われわれの検討では，術前照射例の遠 隔成績はむしろ非照射例に比べて不良でありふ，さら に手術時所見あるいは手術後比較的早期に死亡した症 例の剖検所見で照射野外のリンパ節転移が非照射例に 比べて多い傾向を認めた ${ }^{4)}$. 従って, 昭和40年以来われ われは原則として術前照射を行わない方針としてき た.

さらに，食道癌に限らず，癌の治療法は症例ごとに その選択がなされるべさであり，手術により病巣の性 状や進展度が確認されてから合併療法を考慮したほう がより正確な対応となる。それ故，教室では原則とし て術前合併療法は行わず，直ちに切除を行らことを基 本としている.
（昭和38～昭 58 , 東北大 2 外)

$a_{1}$ 症例

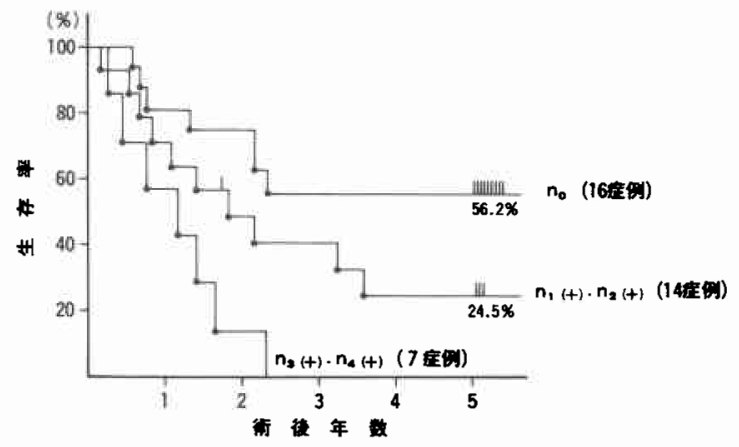

さらに, 今回, 治瘦切除症例について a 因子別生存 率の比較を行ってみた。 その結果, 図 1 に示すごとく, $\mathrm{a}_{3}$ 症例を除いて深達度に拈いて予後には有意の善は認 められなかった。 また, 他藏器浸潤の心配がなく明ら かに治痹切除が可能な $a_{0} \cdot a_{1}$ 症例に特いてn因子別に 生存率の比較を行ってみると, その予後がリンパ節の 転移度により決定されていることが明白であった（図 2). 以上の結果より, 食道癌手術合併療法のほとんど は術後に行らべきであり, 且つ手術時郭清したリンパ 節の転移度により合併療法の種類を決定すべきことが 再確認された。

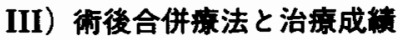
A）治癒切除症例
1）リンパ節転移陰性 $(\mathrm{n}(-))$ 症例
$\mathrm{n}($ （）症例の合併療法別遠隔成績を図 3 に示した。 
図 3 リンパ節転移陰性胸部食道癌合併療法別遠隔成 績

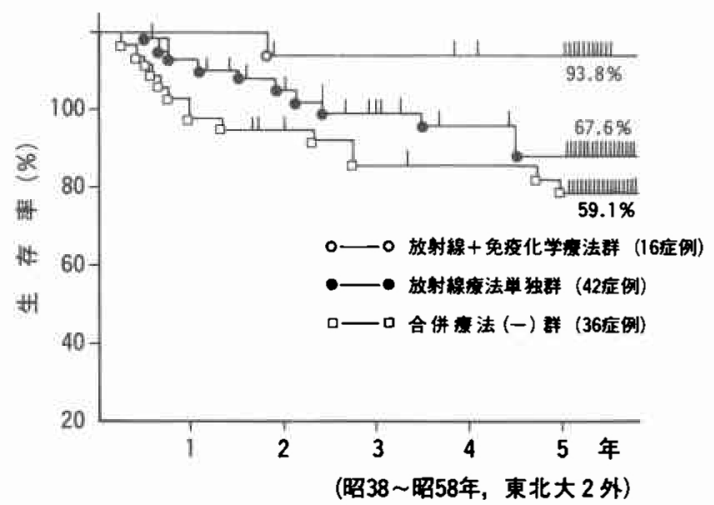

根治手術が可能であった症例の再発部位の多くが頝 部・縦隔であるとの事象に基いて, 昭和 45 年以降教室 で施行してきた術後予防的T字型照射 $(5,000 \mathrm{R})$ は, , 本症例群（42例）に有効で，その 5 生率は67.6\%であ り, 非合併療法症例（36例）の59.1\%より改善をみて いる。一方， T字型予防照射に加兄て兔疫化学療法を 施行した16症例の 5 生率は93.8\%と高值を示した。

以上の結果から，本年度より $\mathrm{n}($ (一)症例に対しては 照射単独療法は行わず，4,000RのT字型照射ととも に, 照射期間にBleomycin $100 \mathrm{mg}$ と Tegafur 600〜750mg/日を同時併用する方針に変更した. また， OK-432ゃ PSK などの Biological Response Modifier は，照射終了後に長期間投与することとした。

一方, $\mathrm{n}(-)$ の ep, $\mathrm{mm}$ 癌症例では再発例を全く経 験していないため, これらの症例に対しては合併療法 を一切行わず，可及的早期に退院させることにした。

2) 近位リンパ節転移陽性 $\left(\mathrm{n}_{1}(+), \mathrm{n}_{2}(+)\right)$ 症例 $\mathrm{n}_{1}(+) \cdot \mathrm{n}_{2}(+)$ 症例のうち, 術後照射単独群 14 症 例の 5 生率は $10.7 \%$ であり, 非合併療法群 30 症例のそ れは $22.9 \%$ ですた。一方，前述の照射に免疫化学療 法を併用した症例の 5 生率は $34.9 \%$ 之応の改善をみ ている(図4).しかしながら， $\mathrm{n}_{1}(+) \cdot \mathrm{n}_{2}(+)$ 症例 はR-II の手術によってリンパ節郭清がほとんど成さ れているにもかかわらず，その予後は決して満足のい くものではない.そこで, 照射免疫化学療法が無効で 本療法施行後早期に再発した症例の検討を行ってみ た. その結果, これらの症例の特徽は、リンパ節転移 部位が胸腹部になたがる例， 3 個以上のリンパ節転移 陽性例, $\mathrm{ly} \cdot \mathrm{v}$ 陽性例, 壁内転移陽性例, 腫崵先進部の 小型円形細胞浸潤が軽度の例, 腫場細胞の DNA histo-
図 4 近位リンパ節転移陽性 $\left(\mathrm{n}_{1}(+), \mathrm{n}_{2}(+)\right)$ 胸部 食道癌の合併療法別遠隔成績

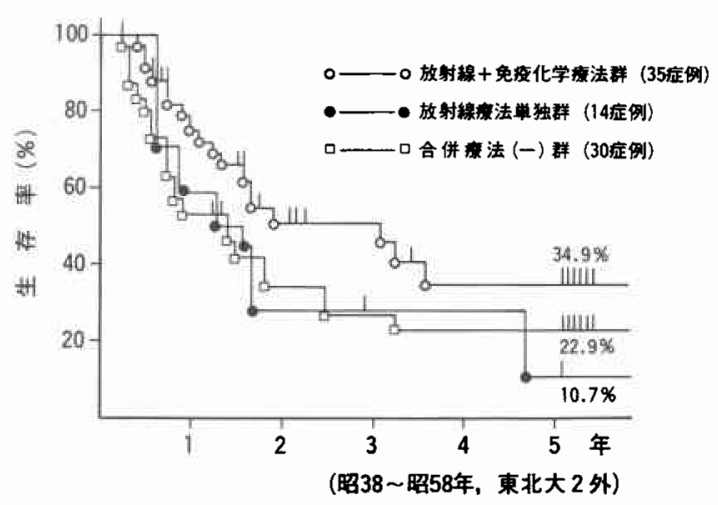

gram で 4 倍体以上の細胞比率が大である症例などで あった。

以上の結果より, $\mathrm{n}_{1}(+) \cdot \mathrm{n}_{2}(+)$ 症例の合併療法 は照射免疫化学療法を行らが，上述の因子を複数有す る症例に対しては次に述べる術後強力癌化学療法を施 行する方針とした。

3）遠位リンパ節転移陽性 $\left(\mathrm{n}_{3}(+) \cdot \mathrm{n}_{4}(+)\right)$ 症例

転移がすでに照射の範囲を越えて払がっていると思 われる本群の症例では, 合併療法の主体が照射では有 り得ない事は明らかである、事実, 従来のいかなる療 法も延命に効果がなく，その 2 生率はわずか $6 \%$ あ り，3年生存例は皆無であった（図 5 ).

それ故, 4 年前より本症例群に対しては, 術後可及 的早期より術後照射を行わず図 6 に示す強力癌化学療 法 (Adriamycin $2 \mathrm{mg} / \mathrm{kg}, 2$ 回, Mitomycin 0.3 0.6 $\mathrm{mg} / \mathrm{kg}, 2$ 回, Pepleomycin 80mg) を Angiotensin II による昇圧下に施行することにした，さらに，術後約 1 年目には Cisplatin $\left(50 \sim 100 \mathrm{mg} / \mathrm{m}^{2}\right)$ と Vindesine

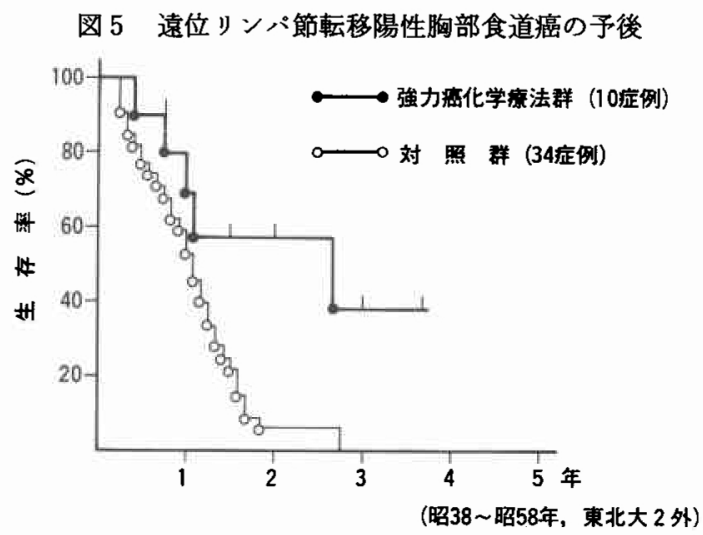


図 6 胸部食道癌術後強力癌化学療法 (Aggressive chemotherapy) スケジュール (PAM 療法)

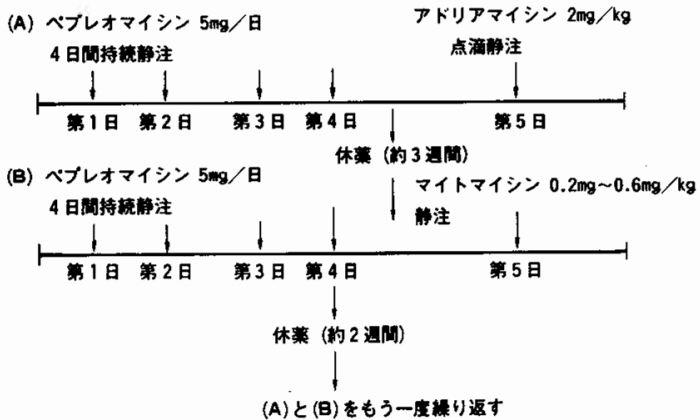

行嗖 1 年目

シスブラチン $50 \sim 100 \mathrm{mg} / \mathrm{m}^{2}$ 点滴贯注

ビンデシン $2 \mathrm{mg} /$ 日 2 日間持勧点

(2mg/日，2 日間)を alternative chemotherapy の意 味も含めて追加投与する. 本療法の施行により, 白血 球减少, 血小板減少, 食欲不振, 呕気, 脱毛などが必 発であるが，静脈栄養あるいは経管栄養による厳格な 栄養管理 (45Cal $/ \mathrm{kg} /$ 日) のもとに遂行する.

本療法による現在までの $\mathrm{n}_{3}(+) \cdot \mathrm{n}_{4}(+)$ 症例の成 績は 1 生率 $68 \% ， 2$ 生率 $56 \% ， 3$ 生率38\%であり（図 5 ), 4 年以上生存例む得ている. このように, 本療法 は著明な予後の改善をむたらしたが，70歳以上の 2 症 例を肺線維症で失ったため, 現在は65歳以下の症例に 適用している，さらに，2例に遷延せる骨髄機能低下 を来たして拈り，今後本療法を積極的に行らべく自家 骨慖移植の臨床応用に取り組みつつある。

4）リンパ節転移陽性表在癌について

教室の早期癌17例と転移陽性表在癌10例の予後には

図 7 食道早期癌症例と食道表在癌症例の生存率の比 較

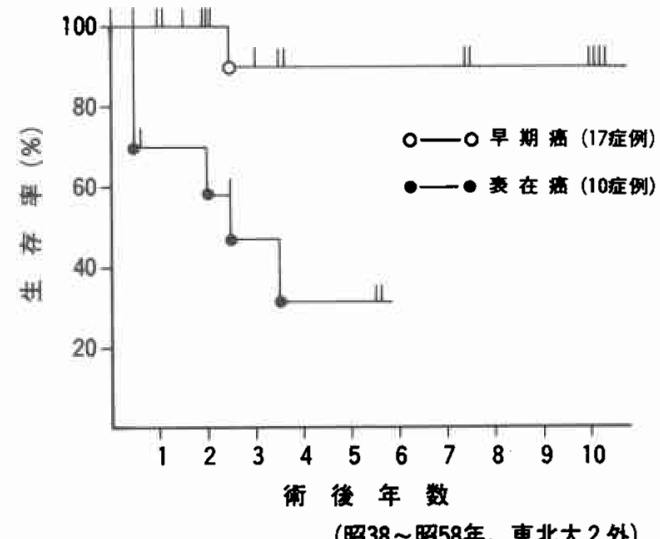

際立った相違を認め，早期癌の 10 生率が $86 \%$ あるあ に対して転移陽性表在癌の 3 生率は30\%である（図 7).さらに, 最近両者の DNA histogram には明らか な相違があり, 転移陽性表在癌では DNA 平均値及び Tetraploid 以上の細胞出現頻度が有意に高い事実が 判明した5)。このように, 転移陽性表在癌は早期に転移 を来たす悪性度の高い癌腫と判断されるため, 本症例 群に対しては前述の術後強力癌化学療法を施行する方 針とした。

\section{B）姑息切除症例}

癌組織が明らかに遺残した姑息切除症例の予後は不 良であり, 術後合併療法非施行例及び術前照射例は全 例 2 年以内に死亡している。一方, 術後に残存部照射

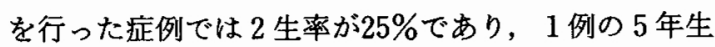
存例子得ている(図 8). 姑息切除例に扣いても, 残存

図 8 胸部食道癌姑息切除耐術症例の遠隔成績 （昭和 $38 \sim$ 昭 58 , 東北大 2 外)

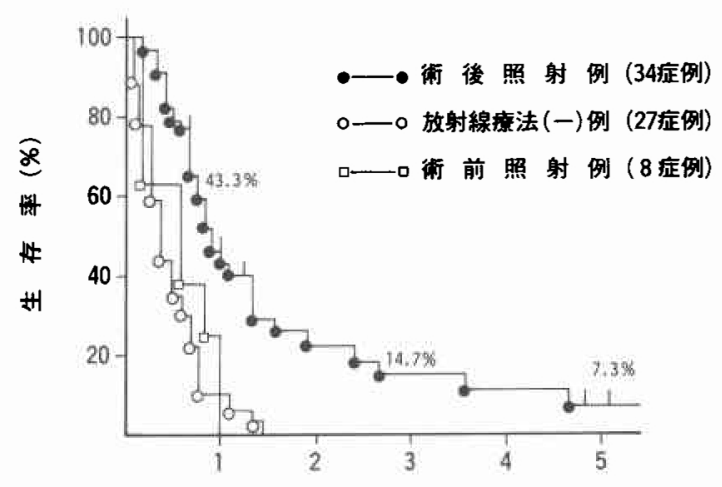

術 後 年 数

図 9 食道癌症例に対する我々の治療方針

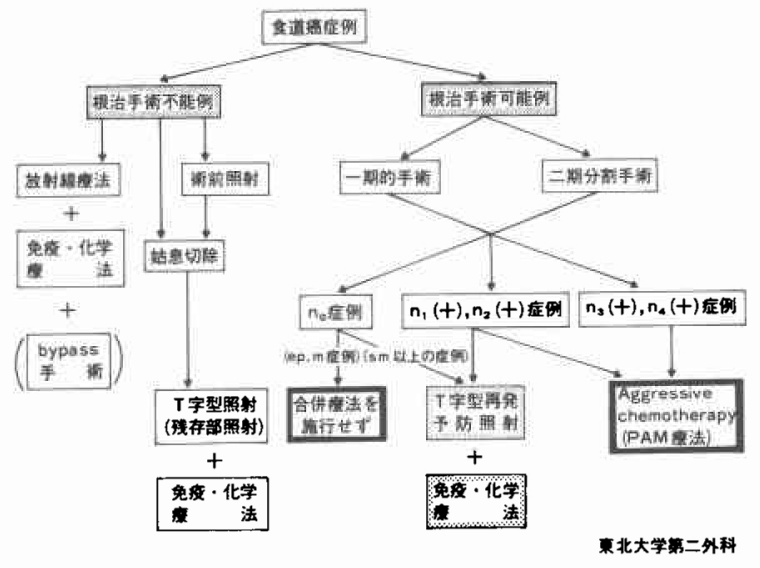


部照射に延命効果を認めた長期生存例は $\mathbf{n}(-)$ 例で あることが多い(6). 姑息切除例は, 残存部照射後早期に 退院させ, 日常生活に復帰させるようにしているが, 遺残癌組織が少量で長期生存を期待しらる場合には化 学療法を追加する.

$$
\text { おわりに }
$$

以上，現在われわれが行っている食道癌に対する治 療方針をまとめたのが図 9 である。

胸部食道癌症例の遠隔成績は, $\mathrm{n}(-)$ 症例では根治 切除ができれば術後予防照射と免疫化学療法の併用に よりほぼ治瘦が可能となった. $\mathbf{n}(+)$ 症例及び姑息切 除症例の予後の向上が今後に残された課題であろう。

$$
\text { 文献 }
$$

1）葛西森夫：食道癌の外科治療一成績向上の道程.
日外会誌 $81: 845-853,1980$

2) 中山佰明, 吉田 充, 楖沢文䕒伍か：消化器癌に対 する術前照射について一特に食道癌並びに胃癌の 理論的根拠一。 日外会誌 $61: 1082-1083,1960$

3）後藤忠司：食道癌術前照射に䍑する臨床的並び沉 病理組織学的研究。日外会誌 $67: 2094-2111$, 1967

4）立花孝史：胸部食道癌の淋巴節転移に関する臨休 的並びに病理組学的研究. 日外会誌 72 : 891-963, 1971

5）小関和士, 栗谷義樹, 豊田統夫ほか：DNA Histogramからみた食道早期癌および食道表在癌の検 討. 日外会誌 $85 ： 548-554,1984$

6）平山克, 西平哲郎, 葛西森夫法：胸部食道癌姑 息切除例の検討. 日消外会誌 $16: 818-824,1983$ 